\title{
Gender and the Performance of Informal Sector Enterprises
}

\section{Olakunle Jayeola,}

Department of Business Administration, Faculty of Social and Management Sciences, Adekunle Ajasin University, Akungba Akoko, Ondo State, Nigeria

\section{Shafie Sidek,}

Department of Management and Marketing, Faculty of Economics and

Management, Universiti Putra Malaysia, Serdang, Selangor, Malaysia

\section{Idowu Owoeye, Yusau Kunle Kazeem,}

Department of Business Administration, Faculty of Social and Management Sciences, Adekunle Ajasin University, Akungba Akoko, Ondo State, Nigeria

\begin{abstract}
The objective of the study was to examine whether female and maleled informal businesses differ in terms of performance. Using a simple random sampling, 250 paper questionnaires were distributed by hand to small and micro enterprises, out of which 90 responses were gathered from owners and managers of informal enterprises. The Upper Echelon Theory (UET) serves as the main theory that underpins this study. Mann-Whitney test was employed to test the study's hypotheses. The findings of the study revealed that there was a significantly equal relationship between gender and profit. Sales and gender performance however indicated a non-significant relationship. Female-led enterprises had a significantly higher employees' growth than male-led enterprises. Overall, female outperformed male in the informal sector based on employees' growth which is an indication of female's lenient, empathetic and good leadership style than male.
\end{abstract}

Keywords: Gender, Informal sector, Small business, Enterprises, Performance, Ondo state

\section{Introduction}

Globally, two main types of economy exist in every country of the world, namely; formal and informal economy (Yusuff, 2011). The formal economy is the economic sector that is characterised by regular work, legal approval and regulation by the government. In comparison, the informal 
economy is just the antithesis of the formal economy. It is defined as a sector that depicts erratic work, illegal operation and lack of government regulation of any kind (Portes, Castells, \& Benton, 1989). It is typically used with reference to employment external to formal regulatory arrangements, either in practice or law (ILO, 2014). The idiomatic term "off the books" literally sums it all as it contains the non-regulated character of the sector, outside the taxation regime and formal regulation exclusion (Martínez, Short, \& Estrada, 2017).

The informal economy dominates most developing economies and it is the focus of this study. For example, informal sector constitutes the bulk of Nigerian economy and contributes significantly to the Gross Domestic Product (GDP), employment and overall economic development of the country (Fasanya \& Onakoya, 2012; Omisakin, 1999). The term informal economy is applicable to micro or small enterprises that starts as personal or family self-employment business. It includes production, processing and cross-country trading. Some of these activities revolve around lack proper business permit, tax avoidance, non-compliance with labor laws, improper work conditions and governing contracts plus the non-existence of lawful contractual agreement between suppliers and customers (Bromleys 1978; Fasanya \& Onakoya 2012). Consequently, the informal sector attracts both male and female of diverse backgrounds for various reasons, however whether male outperform female in this sector or vice-versa remains an unexplored empirical question.

In the present economy, gender has a concrete impact on performance of business because gender influences the formulation and execution of strategies (Boohene, Scheridan, \& kotey, 2008). Gender has its origin in social institution and results in patterns in society that form associations between male and female that give them opposing position of merit and demerit within the institution (Anderson \& Colins, 2001). In a developing nation like Nigeria, gender role is seen as prescribed expectation and obligations, responsibilities and behavior of masculine and feminine gender (Ezumah, 2003). It is worthwhile to note that Nigerian society is patriarchal in nature signifying male dominance of a typical traditional society (Allanana, 2013), thus, female are believed to always take the back seat in every interpersonal and economic relationship. Oyekanmi (2004) in his definition posits that patriarchy is a set of collective dealings with material support that allows male to control female. Hence, the general assumption is that male gender is more likely to outperform the female gender in all forms of businesses including the informal sector. Even with this assumption, this issue has thus not received the scholarly attention it deserves, especially in Nigeria.

Gender and entrepreneurship scholars have been studying the relationship between performance of male-owned and female-owned 
businesses for almost thirty years now (Sappleton, 2018). This body of research is partially the cause of the widely held hitherto contentious belief that the enterprises owned and managed by female are not as much successful than those owned by their male counterparts in terms of economic metrics such as international operation, business size, sustainability, growth prospect, profitability and sales (Zolin, Stuetzer, \& Watson, 2013). Nevertheless, this "gender performance dichotomy" is far from being resolved as efforts are still being made by different researchers to unravel patterns of business performance between male and female in different contexts.

Previous studies have examined gender and performance issues in different contexts and sectors; however, the informal sector has been neglected. For example, gender and performance studies have been conducted in the contexts of large enterprises (Ali \& Shabir, 2017; Khan \& Vieito, 2013; Perryman, Fernando, \& Tripathy, 2016), SMEs (Khalife \& Chalouhi, 2013; Watson, 2002), public business (Moreno-Gómez, Lafuente, \& Vaillant, 2018), service sector (Hokkanen \& Autio, 1998), hotel (Marco, 2012) and bank (Amore \& Garofalo, 2016). Bird and Brush (2002) posit that gender discrepancies in factors affecting the performance of informal business remain chiefly unaddressed by social scientist and bulk of studies either ignored gender as a variable of concern or neglected female subject from their study. Robb and Watson (2012) further argue that one important factor that has been identified in the literature when studying gender performance is the industrial sector in which male and female enterprises are located. Despite this observation, Sappleton (2018) observes that prior studies continue to neglect the impact differences business sector exerts on firm's success, survival and performance. This implicates that different sectors will give different results when gender is compared based on performance metrics.

Therefore, there is need to investigate whether businesses owned by male significantly differ in terms of performance to businesses owned by female in the informal sector. The study was conducted in two neighboring towns- Ikare and Akungba Akoko, Ondo state. These towns are predominantly commercial hub in the state. They have hundreds of small businesses largely in the informal sector. This study contributes to the growing body of literature on gender and business performance but in a unique way by focusing on the informal sector. It is thus of great policy importance to investigate such important relationship. The research question this study seeks to answer is: Does any difference exist between male and female informal business performance in the informal sector?

The paper is organised as follows: Section 2 discusses the theoretical framework. Section 3 presents the literature review and hypotheses. Section 4 describes the research methodology. Section 5 explains the research findings 
and result, and Section 6 presents the conclusions. Limitations of the study and future research are discussed in section 7.

\section{Theoretical Framework}

For this study's theoretical framework, the upper echelon theory (UET) was drawn upon (Hambrick \& Mason, 1984). Though other theories like social categorisation theory (Tajfel, 1981), critical mass theory (Kanter, 1977) and social identity theory (Ashforth \& Mael, 1989) have been utilised to link female and business performance (Moreno-Gómez et al., 2018), the UET provides a clearer theoretical support for linking specific owner or manager demographic characteristic such as gender (male and female) to firm performance.

From the UET point of view, a firm is a manifestation of its top managers (Hambrick \& Mason, 1984). UET states that enterprises outcomes such as strategic choices and performance are partly explained by managerial background characteristics, that is, the values of managers and the cognitive rationale for these values. The basis for UET rests on the hypothesis that the meanings that top management make of the conditions they encounter, and consequently the choices and decisions they make are significantly influenced by their personal experiences, personalities and values (Hambrick, 2007). Managers or owners characteristics serve to filter and distort the abundant information that confronts them (López-Muñoz \& Escribá-Esteve, 2017; Ocasio, 1997). Put differently, behavioural factors, such as attention to multiple and conflicting objectives, bounded rationality and various ambition levels, evidently influence the managers' strategic decision (Nielsen, 2010).

Nishii, Gotte \& Raver (2007) argue that as part of the peculiarity and personal traits that typify top executive, gender is a key characteristic to be considered according to the UET; and it would determine the performance of firms being managed. It can be sufficed that the performance of informal sector businesses hinges on the specificities of people in charge of their management- entrepreneurs as owners or managers. Research studies using the UET as a theoretical lens have used two special units of analysis, namely, the executive team and the individual CEO (Jeong \& Harrison, 2016). The present research embraces the individual CEO unit of analysis as it is suitable for individual difference-based theorising (Moreno-Gómez et al., 2018). In addition, it is assumed that informal sector businesses are usually run in small entity establishment, owned and managed by one or a few persons with nominal capital (Fasanya \& Onakoya, 2012). This study therefore focuses on the gender diversity at the individual level of management of informal sector businesses (in this study's case, as owner or manager). 


\section{Literature Review and Hypotheses}

The association between gender and enterprise performance is a rather novel area of investigation (Khan \& Vieito, 2013). Empirically, evidence exists to point out that gender has been a major demographic variable which impacts the decision-making and business performance (Chirwa, 2008; Lee \& Marvel, 2014; Rodriguez-Dominguez, García-Sánchez, \& Gallego-Álvarez, 2012). Nonetheless, the relationship linking gender and enterprise performance is a rather less investigated area (Bardasi, Sabarwal, \& Terell 2011; Khan \& Vieito, 2013). In addition, most research on gender disparity in business performance are focused on western nations (Boohene et al., 2008), while developing countries have received less attention.

Some studies have found gender differences in business performance, while there are researchers who have found mixed or no relationships between male versus female and business performance (Johnsen \& McMahon, 2005; Diaz-Garcia \& Brush, 2012; Lee \& Marvel, 2014; Watson, 2012). Based on the patriarchal nature of most societies, vast bulk of the literature suggests that male typically occupies leading positions in the labour force and economy (Kalleberg \& Leicht, 1991). Additionally, the literature indicates that commonly, female-owned enterprises underperform in comparison to maleowned enterprises (Chell \& Baines, 1998; Lee and Marvel, 2014).

The association between gender and the performance of small business is multifarious, however, gender seems to be a major determinant of SMEs' performance in Great Britain (Rosa, Carter, \& Hamilton, 1996). Chirwa (2008) empirically established that while no significant distinction exists in profit margins, female-owned firms probably appears to grow more quickly in employment than male-owned firms in Malawi's micro and small enterprises (MSEs). Robb and Watson (2012) highlighted that female who are planning to start a new business are not dissuaded from the erroneous idea that new business start-up by the female gender are unlikely to be successful than those started by male. Davis, Babakus, Englis, \& Pett (2010) contend that femalemanaged small businesses do considerably better based on their very high market orientation as opposed to those managed by male.

The study of Alowaihan (2004) in Kuwait focused on small firms and the analysis of the relationship between gender and business performance was performed. The results of the study revealed that female performed worse compared to male on gross revenue and income. The author concluded that female-owned enterprises under-performed financially because of the newness liability. Furthermore, Johnsen \& McMahon (2005) examined the extent to which the owner-manager gender affected the financial performance (Return on equity (ROE) and Return on total assets (ROA) and business growth (growth in employees number, sales growth and assets growth) of more than 2000 SMEs in Australia. Authors reported that there was no 
statistically significant distinction in business growth and financial performance between male and female owner-managed enterprises. Ali and Shabir (2017) studied the difference between the performance of female and male-owned enterprises and obstacles in India revealed that female-owned enterprises performed better than their male counterparts on annual sales growth and annual labour productivity. Male-owned enterprises outperformed female-owned on capacity utilisation. But on employment, there was no significant difference across both genders. Overall, female perceived less business obstacles compared to male.

Du Rietz \& Henrekson (2000) found that female-managed businesses underperform compared to male-managed enterprises in terms of sales growth, profits, employment and commissions/orders. Meanwhile, gender's significant influence on performance fizzled out when firm size, industry and sector were controlled for, and there were no differences in the performance of soleproprietorship businesses. Hokkanen \& Autio (1998) limited their sample to businesses above three years old in the service sector and compared the performance of male and female on some performance parameters such as employee size, sales, sales growth, employees' size growth and growth aspirations. The results showed that gender was not correlated with any of the performance metrics. Watson (2002) using nearly 5000 SMEs in Australia, discovered that income and profit of enterprises owned by male were averagely higher, while return on assets (ROA) and return on equity (ROE) (which Watson contends are more practical measures of profitability than sales and profit) were higher for female-owned business. The implication of this result indicates that female-owned businesses performed better than maleowned businesses.

Khalife \& Chalouhi (2013) compared 30 female-owned and menowned small firms in Lebanon, principally on business performance. The study found that female-owned firms produced lesser gross revenue in relation to their male-owned counterparts. However, there was no significant difference between male and female-owned firms in terms of their incomes. The authors found that the variation in gross revenues were accounted for by some owner's characteristics such as education level, experience, firm's age and size. Moreno-Gómez et al. (2018) examined how gender diversity in top management affected the performance of Colombian public businesses. The results of the study indicated that more female in boardroom was significant with return on equity (ROE) and the proportion of female on the top management team (TMT) showed a significant relationship to return on asset (ROA) and ROE.

Chadwick \& Dawson (2018) investigated how female and malemanaged family and non-family businesses differ in terms of financial and non- financial business performance using panel data of large public 
organisations from the S\&P 500. The outcome of the research showed that female-led organisations outperformed male-led organisations in terms of non-financial performance in both family and non-family businesses. However, female-led organisations had significant and positive relationship with financial performance only in non-family business. Although the leading view in the literature is that female-owned firms under-perform in relation to those owned by male (Chell \& Baines, 1998; Lee \& Marvel, 2014; Sappleton, 2018), the above discussion of literature however could not support such view. The results appear to be conflicting as both men and women outperform each other in different contexts and based on some specific factors. Stated formally, it is hypothesized that:

Hypothesis 1. Informal business managed by male will not display any significant difference in profit to informal business managed by female.

Hypothesis 2. Informal business managed by male will not display any significant difference in sales to informal business managed by female.

Hypothesis 3. Informal business managed by male will not display any significant difference in employees' growth to informal business managed by female.

\subsection{Conceptual Framework}

Based on the above discussion and hypotheses, the conceptual framework of this study is presented in Figure $\mathbf{1}$ below. The framework depicts the direct relationship between the independent variable (gender) and the dependent variable (financial and non-financial performance).

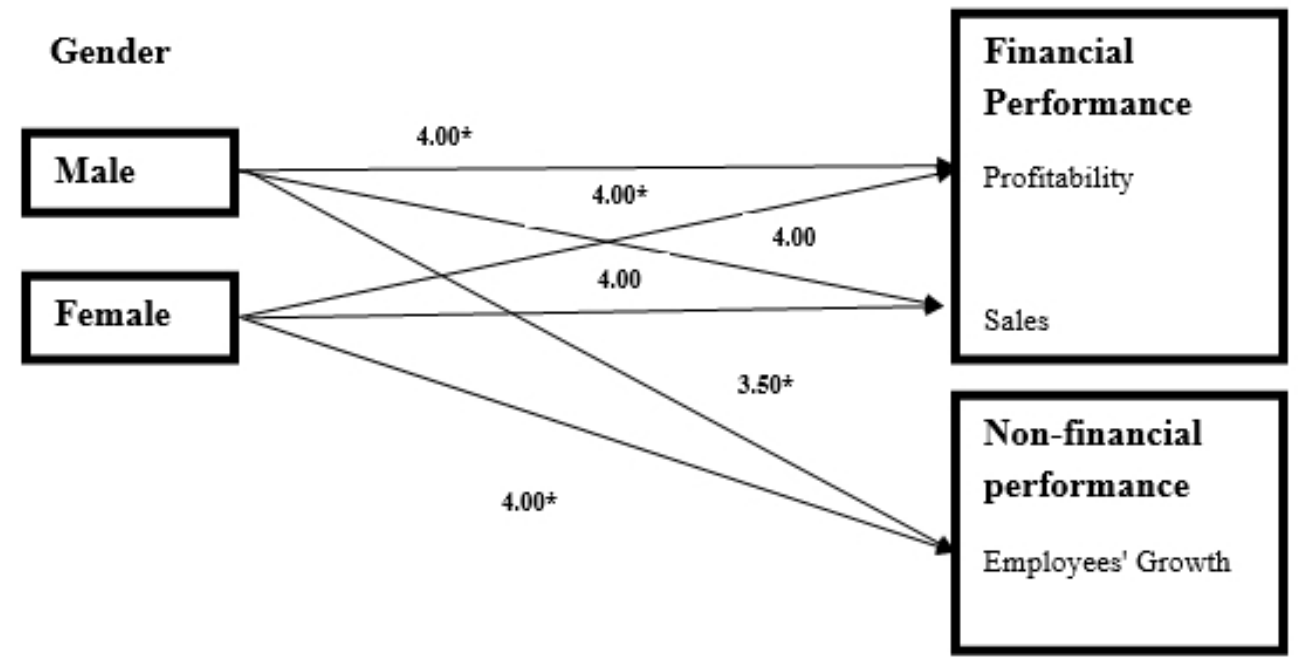

Figure 1. Conceptual framework of gender and performance of informal sector businesses 


\section{Methodology}

A simple random sampling technique was used in this study. Small and micro enterprises were randomly selected in the study area. 250 paper questionnaires were initially distributed by hand to small and micro enterprises' managers and owners. Phone contacts of all potential respondents were collected for reminder and follow-up. After many calls and some personal visits, a total of 101 fully filled questionnaire were returned. The questionnaire was scrutinized, and it was observed that 7 enterprises answered being registered with the regulatory agencies. These questionnaires were removed because such enterprises belong to the formal sector and are outside the scope of this study. 94 responses by owners and managers of informal businesses were returned, a response rate of $37.6 \%$.

4 responses were discarded because they contained incomplete or missing values and 90 were used for this study. A Likert scale of 1-5 was used for the dependent variables where 1 was considered as strongly disagree, 2 as disagree, 3 as neutral, 4 as agree and 5 was considered as strongly agree.

Cronbach's $\alpha$ is the most accepted reliability test, which gauges the internal consistency of an instrument (AL-Shboul, 2018). According to Nunnally (1978) an $\alpha$ score higher than 0.7 is acceptable for all constructs in a study. This is the threshold at which the variables' correlation are significant. In this study, all constructs were measured and had an adequate $\alpha$ higher than 0.7 , hence significant. Two senior management and business faculty members (Professor and Associate Professor) validated the questionnaire before administration.

The main statistical software used for data analysis of this study was SPSS 23. Frequencies and percentage were employed in the study to analyse the respondents and organisations' demographic profiles. The Mann-Whitney $\mathrm{U}$ test was used to test the hypotheses. According to Walters (2011), the Mann-Whitney test is the nonparametric substitute to the independent-samples t-test and a very powerful nonparametric statistical test. Usually, it assesses the distinctions in two equally exclusive groups when normality assumption is not met, for example many outliers or when the dependent variable is an ordinal scale. This study opted for Mann-Whitney U test because the data were not normally distributed as observed from the histogram and box plots of SPSS outputs. Transformation of variables to generate normal distributions was not done because of interpretation difficulties frequently caused by such measures (Johnsen \& McMahon, 2005). Furthermore, this study used ordinal scaleLikert scale and the independent variable is categorical.

The independent variable in the study is Gender, either male or female. The dependent variables in this study are the performance measures of informal business. Generally, performance is measured financially and nonfinancially. Financial performance measures the overall financial health of 
firms overtime (Jayeola, 2015) and non-financial performance measures other vital qualitative metrics in the firm. The combination of these two performance measures provides a strong and holistic firm performance (Jayeola, Ihinmoyan, \& Kazeem, 2018). As a result, profitability and sales were used for the financial measurement of performance and employee's growth for nonfinancial performance. The performance constructs were measured on "improvement" of each construct in the last two years, on a five-point Likert scale.

\section{Research Findings and Discussion}

The findings of the research are discussed in this section. The respondents and organisations' demographic profiles are presented in Table 1. The table shows that majority of the respondents are male $(61.1 \%)$, an indication that males participate more in informal business than female in the study area. Participation of more male in this study is somehow paradoxical to the general literature view that female participate in informal economy than male because it provides flexibility in terms of working hours, closeness of the job to one's home and pace of work (Babbitt, Brown, \& Mazaheri, 2015; Bahramitash \& Salehi Esfahani, 2011). It is not surprising to have more owners (58.9\%) as respondents than managers, as informal businesses are small and generally managed by owners themselves. Majority $(36.7 \%)$ of the respondents are secondary school leavers and $33.3 \%$ are Bachelor of science (BSc) degree holders. This is an indication that participation in informal economy does not owe to lack of education. The vast majority (43.3\%) of the informal businesses started operation between 1 and 5 years and few about $19 \%$ are 11 years and above. It can be concluded that with time passage and more visibility in terms of expansion, informal businesses tend to formalise their operations and exit the informal sector. The concentration of $(50 \%)$ in the retail and wholesale sector justifies the ease of start-up, i.e.- buying and selling in stalls, roadside kiosks etc. 
Table 1. Respondents and organisations' demographic profiles

\section{Profiles}

Sex

Male

Female

Position

Owner

Manager

Educational qualification

Primary school certificate

SSCE/GCE

NCE

OND/HND

BSC

MSC

\section{Frequency Percentage}

\section{5}

35

38.9

58.9

41.1

\section{7}

36.7

4.4

17.8

33.3

1.1

Enterprise working in business

less than 1 year $\quad 10$

1-5 years

6-10 years

11-15 years

7.8

16 years and above

Enterprise sector

Retail and wholesale

50.0

Services

Manufacturing

8.9

Agriculture

Health

The examination of Mann-Whitney test output in Table 2 shows the difference between the performance of male versus female owned or managed informal businesses. The last column shows the effect size. Pallant (2010) explains that SPSS does not calculate the effect size statistics, but the $\mathrm{Z}$ value from the output can be used to compute an estimated value of $r . r=z$ / square root of $\mathrm{N}$, where $\mathrm{N}=$ number of sample. Effect size defines how substantially two groups are; the magnitude of the phenomenon and it is independent of sample size (McLeod, 2019). Thus, an effect size of .1(small effect size), .3 (medium effect size), .5 (large effect size) is postulated by Cohen (1988).

For the performance variable of profit, the result indicates a statistically significant result between male and female, however, there was no difference in the median score for both gender and a small effect size was noticed ( $\mathrm{Md}=4.00$, male; $\mathrm{Md}=4.00$, female, $\mathrm{Z}=-1.990, \mathrm{p}=.047, \mathrm{r}=0.21)$. Therefore, H1 is partially accepted, because the Informal business managed by male did not display a difference in profit to informal business managed by 
female, but the result was significant. Meanwhile, the effect size was small. The implication of this result is that male and female perform equally in terms of profit in the informal sector, although the equality in performance is not strong. This result contrasts with the result of Chirwa (2008) that found no significant relationship between men and female owned enterprises in Malawi.

For the performance variable of sales, the result shows a nonsignificant, a relatively equal median score between male and female and a small effect size $(\mathrm{Md}=4.00$, male; $\mathrm{Md}=4.00$, female, $\mathrm{Z}=-1.245, \mathrm{p}=.213, \mathrm{r}=$ 0.13 ). Therefore, $\mathrm{H} 2$ is accepted, because informal business managed by male did not display any significant difference between male versus female. This result is congruent with previous studies of Johnsen and McMahon (2005) and Hokkanen and Autio (1998) that found non-significant relationship between sales and performance of male and female enterprises. Sales has a small noninfluential effect between male versus female enterprises.

Employees growth shows a significantly different pattern between male versus female and with very close to medium effect size $(\mathrm{Md}=3.50$, male; $\mathrm{Md}=4.00$, female, $\mathrm{Z}=-2.763, \mathrm{p}=.006, \mathrm{r}=0.29$ ). Thus, $\mathrm{H} 3$ is rejected, as informal business managed by male does display a significant lower difference in employees' growth to informal business managed by female, with nearly a medium effect size. This result is supported by Chirwa (2008) who found a higher employment growth for female enterprises than male enterprises. The higher employment growth of female indicates that female-led enterprises are more likely to have more capable and willing people to work in them than men-led enterprises.

Table 2. Two-tailed Mann- Whitney test outputs

\begin{tabular}{|l|l|l|l|l|l|}
\hline Variable & $\begin{array}{l}\text { Male }(\mathbf{n}=55) \\
\text { Median }\end{array}$ & $\begin{array}{l}\text { Female }(\mathbf{n}=\mathbf{3 5}) \\
\text { Median }\end{array}$ & $\mathbf{Z}$ & Significance* & $\begin{array}{l}\text { Effect size (r) } \\
\mathbf{z} / \sqrt{\mathbf{N}}\end{array}$ \\
\hline Profit & 4.00 & 4.00 & -1.990 & .047 & 0.21 \\
\hline Sales & 4.00 & 4.00 & -1.245 & .213 & 0.13 \\
\hline Employees' growth & 3.50 & 4.00 & -2.763 & .006 & 0.29 \\
\hline
\end{tabular}

\section{Conclusion}

The main objective of this paper was to ascertain if any difference exists in terms of performance between male and female owned or managed enterprises in the informal sector. However, the review of the literature revealed that mixed findings dominate the literature. Hence, it was hypothesized that there would not be significant difference in performance between male versus female enterprises in the informal sector. The findings indicate that there was no difference between male-led and female-led enterprises in terms of profit, nevertheless, the result was significant. Hence, H1 was partially accepted. Male and female are equal in their respective business strategies and skills and the tendency to outperform each other in profit generation is unrealistic. 
In addition, male and female informal businesses exhibited the same level of sales, but it was insignificant. Therefore, $\mathrm{H} 2$ was fully supported. The equality of male and female enterprises in terms of sales is not important or valid and it could be due to random chance. In this view, sales equality between female and male enterprises is not a reliable performance indicator. Lastly, employees' growth was statistically significant and higher for female than male-owned or managed enterprises, thus H3 was rejected. Female informal businesses tend to have more manpower growth than male businesses because they can be accommodating, empathetic, lenient and are better leaders than male. Consequently, many people prefer to work in informal enterprises owned or managed by female than male. Overall, it can be concluded that female outperform male in the informal businesses sector.

As a result of the prevalence and importance of informal economy in contributing to the GDP and employment in Nigeria, the findings of this study can be useful for policymakers to implement policy to support the performance of this sector. It is recommended that government should take into consideration the different outcomes of this study and formulate policies accordingly. Though no difference was observed for both gender in terms of profit and sales, government needs to devise more schemes to help them access credit to improve their performance. Access to more credit schemes for better performance should be reinforced with adequate training in human resources management, especially in male-led informal sector that have a comparatively lower employees' growth. Both male and female owned, or managed informal enterprises should further strive to improve their business performance continuously by availing themselves of training opportunities by government and through self-development. Male-led informal businesses need to change their leadership styles, especially in dealing with their employees.

\section{Research Limitations and Future Research}

In this study, only the direct relationship between gender and performance were considered. Other owners/managers and enterprises' characteristics such as size, work experience, education, business sector could have effect on the performance of male versus female enterprises in the informal sector. Future studies should control for these characteristics to establish different effect patterns. As such, more advanced statistical technique such as regressions or structural equation modeling (SEM) are recommended.

\section{References:}

1. AL-Shboul, M. A. (2018). Towards better understanding of determinants logistical factors in SMEs for cloud ERP adoption in developing economies. Business Process Management Journal, 25(5), 
887-907. https://doi.org/10.1108/BPMJ-01-2018-0004

2. Ali, J., \& Shabir, S. (2017). Does gender make a difference in business performance?: Evidence from a large enterprise survey data of India. Gender in Management, 32(3), 218-233. https://doi.org/10.1108/GM09-2016-0159

3. Allanana, G. (2013). Patriarchy and Gender Inequality in Nigeria : the Way Forward. European Scientific Journal, 9(17), 115-144.

4. Alowaihan, A. K. (2004). Gender and business performance of Kuwaiti small firms: A comparative approach. International Journal of Commerce and Management, 14(3-4), 69-82. https://doi.org/10.1108/10569210480000185

5. Amore, M. D., \& Garofalo, O. (2016). Executive gender, competitive pressures, and corporate performance. Journal of Economic Behavior and Organization, 131, 308-327.

https://doi.org/10.1016/j.jebo.2016.09.009

6. Anderson, M.I., \& Collins, P.H. (2001). Race, Class and gender (An Anthony ed.). Wadiswooth : Thomas learning.

7. Ashforth, B.E., \& Mael, F. (1989). Social identity theory and the organisation. Academy of Management Review, 14(1), 20-39.

8. Babbitt, L. G., Brown, D., \& Mazaheri, N. (2015). Gender, entrepreneurship, and the formal-informal dilemma: Evidence from Indonesia. World Development, 72, 163-174. https://doi.org/10.1016/j.worlddev.2015.02.019

9. Bahramitash, R., \& Salehi Esfahani, H. (2011). Veiled employment: Islamism and the political economy of women's employment in Iran. Syracuse: Syracuse University Press.

10. Bardasi, E., Sabarwal, S.,\& Terrell, K. (2011). How do female entrepreneurs perform? Evidence from three developing regions. Small Business Economics, 37(4), 417-441.

11. Bird, B., \& Brush, C. G. 2002. A gendered perspective on organisational creation. Entrepreneurship Theory and Practice, 26(3), 41-65.

12. Boohene, R., Sheridan, A., \& Kotey, B. (2008). Gender, personal values, strategies and small business performance: A Ghanaian case study. Equal Opportunity International, 27(3), 237-257.

13. Bromley, R.T. (1978). Introduction- The urban informal sector: Why is it worth discussing? WorldDevelopment, 6, 1033-1039

14. Chadwick, I. C., \& Dawson, A. (2018). Women leaders and firm performance in family businesses: An examination of financial and nonfinancial outcomes. Journal of Family Business Strategy, 9(4), 238-249. https://doi.org/10.1016/j.jfbs.2018.10.002

15. Chell, E., \& Baines, S. (1998). Does gender affect business 
performance? A study of micro businesses in business services in the UK. Entrepreneurship and Regional Development, 10(2), 117-135.

16. Chirwa, E. W. (2008). Effects of gender on the performance of micro and small enterprises in Malawi. Development Southern Africa, 25(3), 347-362. https://doi.org/10.1080/03768350802212139

17. Cohen, J. (1988). Statistical Power Analysis for the Behavioral Sciences (2nd ed.). Hillsdale, New Jersey: Lawrence Erlbaum Associates.

18. Davis, P.S., Babakus, E., Englis, P.D., \& Pett, T. (2010). The influence of CEO gender on market orientation and performance in service small and medium-sized service businesses. Journal of Small Business Management, 48( 4), 475-496.

19. Díaz-García, M.C. , \& Brush, C. (2012). Gender and business ownership: Questioning "what" and "why". International Journal of Entrepreneurial Behaviour \& Research, 18(1), 4-27.

20. Du Rietz, A., \& Henrekson, M. (2000). Testing the female underperformance hypothesis. Small Business Economics, 14(1), 110.

21. Ezumah, N. N. (2003). Gender issues in the prevention and control of STIs and HIV/AIDS: Lessons from Awka and Agulu, Anambra state, Nigeria. Journal of African Reproductive Health, 7(2), 89-99.

22. Fasanya, I., \& Onakoya, A. (2012). Informal sector and employment generation in Nigeria: An error correction model. Research on Humanities and Social ..., 2(7), 48-55. Retrieved from http://www.iiste.org/Journals/index.php/RHSS/article/view/2620

23. Hambrick, D. (2007). Upper echelons theory: An update. Academy of Management Review, 32(2), 334-343.

24. Hambrick, D. C., \& Mason, P. a. (1984). Upper echelons: The organisationa as a reflection of the Its top managers. The Academy of Management Review, 9(2), 193-206. https://doi.org/10.2307/258434

25. Hokkanen, P., \& Autio, E. (1998). Growth performance of femaledriven firms. Proceedings of 43rd ICSB World Congress, Entrepreneurship at the Threshold of the 21st Century, Singapore June, CD-ROM.

26. ILO (International Labour Organisation) (2014). Transition to formality in Latin America and the Caribbean. Lima: ILO, Regional Office for Latin America and the Caribbean.

27. Jayeola, O. (2015). The impact of environmental sustainability practice on the financial performance of SMEs: A study of some selected SMEs in Sussex . International Journal of Business Management and Economic Research(IJBMER), 6(4), 214-230. Retrieved from www.ijbmer.com 
28. Jayeola, O., Ihinmoyan, T., \& Kazeem, Y. K. (2018). Environmental factors and the performance of micro and small scale enterprises (MSEs) in Nigeria: Lessons froms some selected MSEs in Ondo state Nigeria. Journal of Economics, Management and Trade, 21(6), 1-14. https://doi.org/10.9734/JEMT/2018/42079

29. Jeong, S.H., \& Harrison,D. (2016). Glass breaking, strategy making, and value creating: meta-analytic outcomes of females as CEOs and TMT members. Academy of Management Journal, 60(4), 1219-1252. http://doi: 10.5465/amj.2014.0716.

30. Johnsen, G. J., \& McMahon, R. G. P. (2005). Owner-manger gender, financial performance and business growth amongst SMEs from Australia's business longitudinal survey. International Small Business Journal, 23(2), 115-142. https://doi.org/10.1177/0266242605050509

31. Kalleberg, A.L., \& Leicht, K.T. (1991). Gender and organisational performance: Determinants of small business survival and success. The Academy of Management Journal, 34(1), 136-161.

32. Kanter, R.M. (1977). Some effects of proportions on group life: skewed sex ratios and responses to tokenwomen. American Journal of Sociology, 82(5), 965-990.

33. Khalife, D., \& Chalouhi, A. (2013). Gender and business performance. International Strategic Management Review, 1(1-2), 1-10. https://doi.org/10.1016/j.ism.2013.08.001

34. Khan, W. A., \& Vieito, J. P. (2013). Ceo gender and firm performance. Journal of Economics and Business, 67, 55-66. https://doi.org/10.1016/j.jeconbus.2013.01.003

35. Lee, I.H., \& Marvel, M.R. (2014). Revisiting the entrepreneur genderperformance relationship: A firm perspective. Small Business Economics, 42(4), 769-786.

36. López-Muñoz, J. F., \& Escribá-Esteve, A. (2017). An upper echelons perspective on information technology business value. European Research on Management and Business Economics, 23(3), 173-181. https://doi.org/10.1016/j.iedeen.2017.02.003

37. Marco, R. (2012). Gender and economic performance: Evidence from the Spanish hotel industry. International Journal of Hospitality Management, 31(3), 981-989. https://doi.org/10.1016/j.ijhm.2011.12.002

38. Martínez, L., Short, J. R., \& Estrada, D. (2017). The urban informal economy street vendors in Cali, Colombia. Cities, 66, 34-43. https://doi.org/10.1016/j.cities.2017.03.010

39. McLeod, S. A. (2019, July 10). What does effect size tell you? Simply Psychology. https://www.simplypsychology.org/effect-size.html

40. Moreno-Gómez, J., Lafuente, E., \& Vaillant, Y. (2018). Gender 
diversity in the board, women's leadership and business performance. Gender in Management, 33(2), 104-122. https://doi.org/10.1108/GM05-2017-0058

41. Nielsen, S. (2010). Top management team diversity: A review of theories and methodologies. International Journal of Management Reviews, 12, 301-316.

42. Nishii, L., Gotte,A., \& Raver, J. (2007). Upper echelon theory revisited: the relationship between upper echelon diversity, the adoption of diversity practices, and organisational performance. CAHRS Working Paper \#07- 04, Cornell University, School of Industrial and Labor Relations, Center for AdvancedHuman Resource Studies, Ithaca,NY.

43. Nunnally, J. (1978). Psychometric theory. New York, NY: McGrawHill.

44. Ocasio, W. (1997). Towards an attention-based view of the firm. Strategic Management Journal, 18, 187-206.

45. Omisakin I.S. (1999). Factors influencing success or failure of an enterprise in informal sector. NISER Monograph series, 6, 11-54.

46. Oyekanmi, F.D. (2004). Socio-economic dimensions of gender equality in Nigeria. (S.O. Akinboye (ed).). Paradox of Gender Equality in Nigerian Politics, 41-61. Concept Publications, Lagos.

47. Pallant, J. (2010). SPSS survival manual. A step by step guide to data analysis using SPSS (4th ed.). Berkshire: Open University Press.

48. Perryman, A. A., Fernando, G. D., \& Tripathy, A. (2016). Do gender differences persist? An examination of gender diversity on firm performance, risk, and executive compensation. Journal of Business Research, 69(2), 579-586. https://doi.org/10.1016/j.jbusres.2015.05.013

49. Portes, A., Castells, M., \& Benton, L. A. (1989). The Informal Economy. Studies in Advanced and Less Developed Countries. Baltimore and London: The Johns Hopkins University Press.

50. Robb, A.M. and Watson, J. (2012). Gender differences in firm performance: Evidence from new ventures in the United States. Journal of Business Venturing, 27(5), 544-558.

51. Rodríguez-Domínguez, L., García-Sánchez, I.M., \& Gallego-Álvarez, I. (2012). Explanatory factors of the relationship between gender diversity and corporate performance. European Journal of Law and Economics, 33(3), 603-620.

52. Sappleton, N. (2018). Gender and business performance: The role of entrepreneurial segregation. Women Entrepreneurs and the Myth of "Underperformance": A New Look at Women's Entrepreneurship Research, 213-229. https://doi.org/10.4337/9781786434500.00025 
53. Tajfel,H. (1981). Human groups and social categories. Cambridge: Cambridge University Press

54. Walters, R. W. (2011). Database Management , Graphing , and Statistical Analysis Using IBM-SPSS Statistics.

55. Watson, J. (2002). Comparing the performance of male- and femalecontrolled businesses: Relating outputs to inputs. Entrepreneurship: Theory and Practice, 26(3), 91-100.

56. Watson, J. (2012). Networking: Gender differences and the association with firm performance. International Small Business Journal, 30(5), 536-558.

57. Yusuff, O. S. (2011). A theoretical analysis of the concept of informal economy and informality in developing countries. European Journal of Social Sciences, 20(4), 624-636

58. Zolin, R., Stuetzer, M. and Watson, J. (2013). Challenging the female under- performance hypothesis. International Journal of Gender and Entrepreneurship, 5(2), 116-129. 